\title{
Effect of concretion wastes recycled aggregate on concrete performance
}

\author{
Liu Ling ${ }^{1,}$, , Chen Jiguang ${ }^{1, b}$ \\ ${ }^{1}$ Changchun Architecture and Civil Engineering College, Changchun 130607, Jilin, China \\ a52839805@qq.com, b chenjiguang21@sina.com,
}

\begin{abstract}
Keywords: Construction Waste; Recycled Coarse Aggregate; Recycled Aggregate Concrete; Aggregate Replacement Ratio

Abstract. In order to study the difference of recycled aggregate concrete and ordinary concrete in basic mechanical properties. The artificial broken way is applied to abandoned concrete, recycled aggregate and cement slurry soaking are mixed, according to ordinary concrete mix design method of configuration of recycled concrete, concrete with recycled aggregate replacement rate is $0,20 \%, 40 \%$, $60 \%, 80 \%$ is tested. The results show that the compressible strength and elastic modulus of recycled concrete decrease, but the physical properties of recycled concrete can be improved, and the apparent density of recycled concrete can be reduced. When the replacement rate of recycled aggregate is not more than $40 \%$, the high compressible strength can be obtained, and recycled aggregate made of construction waste can be used to replace the natural aggregate to configure recycled aggregate concrete.
\end{abstract}

\section{Introduction}

With the further improvement of science and technology, urbanization has become an urgent need of the country, the construction has been booming in our country. According to the statistics, currently the amount of construction wastes what produced from constructing new buildings and demolishing old buildings has reached to 240-360 million tons, at the same time, because of commercial concrete production, the total amount of natural sand is about 500 million tons each year. The output of such a huge construction waste and Sand and gravel aggregate demand, which is bound to a lot of garbage piled up and quarry, and recycled aggregate concrete can solve the above problem, alleviate the pressure of urban environment, save resources waste and it is widely used, therefore, recycled aggregate concrete and its structure become the hot area around the world[1-6]. According to the size, the recycled aggregate is divided into the recycled coarse aggregate and the recycled fine aggregate. In the waste concrete, mortar, stone, brick and tile are made into recycled coarse aggregate, the particle size is greater than $4.75 \mathrm{~mm}$; Particle size of recycled fine aggregate is not more than $4.75 \mathrm{~mm}$ [7-8]. In this paper, concrete with strength grade $\mathrm{C} 30$ is prepared, the effect of different proportions of recycled aggregate on the strength of concrete $28 \mathrm{~d}$ was found.

\section{Testing situation}

\section{Specimen material}

Abandoned concrete blocks are used as construction waste in laboratory, their strength grade is C30, and they would be broken by hammer crusher. $5 \mathrm{~mm}$ sieve is used for screening aggregate, the particle size of $5-20 \mathrm{~mm}$ is recycled coarse aggregate, the particle size below $5 \mathrm{~mm}$ is recycled fine aggregate and also adopt continuous grading, good grade. Cement is S32.5 P. slag Portland cement; basic properties are shown in Table 1. Natural coarse aggregate using natural stone, the maximum grade is $31.5 \mathrm{~mm}$, asbestos sand in the market is used as fine aggregate, good grade, fineness modulus Mix $=2$. 6 . The basic properties of the coarse aggregate were investigated according to "Standard and Test Method for the Coarse Aggregate of Normal Concrete"(see Table2). 
Tab.1 Basic properties of cements

\begin{tabular}{|c|c|c|c|c|c|c|}
\hline \multirow{2}{*}{$\begin{array}{l}\text { density } \\
\mathrm{kg} / \mathrm{m}^{3}\end{array}$} & \multicolumn{2}{|c|}{ final setting time/min } & \multicolumn{2}{|c|}{$\begin{array}{l}\text { compressive } \\
\text { strength/MPa }\end{array}$} & \multicolumn{2}{|c|}{ flexural strength/MPa } \\
\hline & $\begin{array}{l}\text { Initial } \\
\text { setting }\end{array}$ & $\begin{array}{l}\text { final } \\
\text { setting }\end{array}$ & $3 d$ & $28 \mathrm{~d}$ & $3 d$ & $28 \mathrm{~d}$ \\
\hline 3050 & 170 & 225 & 18.9 & 39 & 4.2 & 7.6 \\
\hline \multicolumn{7}{|c|}{ Tab.2 Basic properties of coarse aggregate } \\
\hline $\begin{array}{c}\text { aggregate } \\
\text { type }\end{array}$ & $\begin{array}{l}\text { particle size } \\
\text { range }(\mathrm{mm})\end{array}$ & $\begin{array}{c}\text { bulk density } \\
\left(\mathrm{kg} / \mathrm{m}^{3}\right)\end{array}$ & & $\begin{array}{l}\text { performance } \\
\text { ensity }\left(\mathrm{kg} / \mathrm{m}^{3}\right)\end{array}$ & $\begin{array}{c}\text { Water } \\
\text { absorption }(\%)\end{array}$ & $\begin{array}{c}\text { Crush } \\
\text { index }(\%)\end{array}$ \\
\hline natural & $5 \sim 31$ & 1453 & & 2820 & 0.4 & 9 \\
\hline recycled & $5 \sim 31$ & 1273 & & 2392 & 1.87 & 13.9 \\
\hline
\end{tabular}

\section{Test methods and production}

According to the Common Concrete Mixture Proportion Design Procedures, firstly , the amount of various materials were determined in common concrete mixture ratio design method, the amount of absorbed water was determined[9-10]. Performance density of ordinary concrete and recycled concrete is $2400 \mathrm{~kg} / \mathrm{m} 3$, the concrete mixture were made of $150 \mathrm{~mm} \times 150 \mathrm{~mm} \times 150 \mathrm{~mm}$ cube specimens, according to the regulations of the "ordinary concrete mechanics performance test method", Concrete was mixed in a capacity of $50 \mathrm{~L}$ mixer, before mixing concrete, Water would be first used to wet the mixer, when the mixer reaches the saturation surface, the sand and the cement are added, then the coarse aggregate is added, and evenly mixed, finally, the water is added. Stirring $3 \sim 5$ min and measuring the slump. If the slump meets the requirement, and the concrete mixture was injected into wood pattern, after $24 \mathrm{~h}$, renovating mould and immediately putting in standard curing room, experiment was carried out after 28d; all specimens were completed for one pouring. For details see attached Table 3 . The specimens included 5 groups; specimen is numbered Z0, ordinary concrete, Z20, Z40, Z60 and Z80 specimens show that the replacement rate of recycled aggregate is $20 \%, 40 \%, 60 \%$ and $80 \%$ of recycled concrete. Each of the 3 specimens for a group, All specimens were tested by "concrete strength test and evaluation standard".

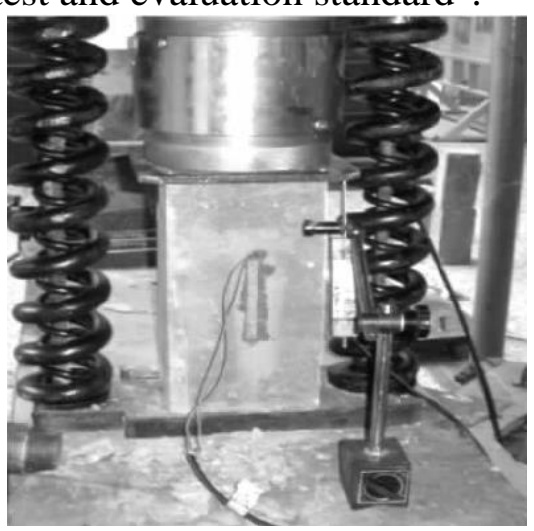

Fig.1 Test device

\section{Test equipment}

Specimen was loaded by hydraulic pressure testing machines; the device is shown in Figure 1. Additional force sensors and springs (spring stiffness is very large) are used to control the speed of the strain, force sensors are mainly used to measure the effect of load on the specimens, The spring is mainly used to bear the residual load after the failure of the specimens, the stiffness of the two springs is higher than the elastic modulus of the specimens design time. At the same time, 4 displacement gauges were installed under the steel plate above the specimens and concrete strain gauge were adhered to the side of the specimens which measure the concrete longitudinal strain. 


\section{Result Analysis}

\section{Influence on Concrete Slump and the Apparent Density}

The mixture ratio of design of concrete and the performance of the mixing materials shown in Table 3. It is observed that, with the proportion of replacement of recycled aggregate in concrete gravel increases and concrete slump values decrease. The reason is that, compared with the gravel, the recycled aggregate has high porosity, high water absorption, rough surface, large surface area and so on, leading to the concrete slump values decrease gradually. At the same time, the apparent density of concrete also showed a decreasing trend, because of the low apparent density of recycled aggregate, which is beneficial to reduce the weight of concrete and improve the seismic performance of concrete structures.

\section{Influences on Compressive Strength of Concrete}

(1) Influence of construction waste added to concrete on mechanical properties of concrete is shown Table 3. As can be seen from table 3, when the replacement ratio of recycled aggregate concrete is controlled in the range of $0 \sim 40 \%$, the recycled aggregate has little effect on the compressive strength of concrete, and the compressive strength is equal to the value of the ordinary concrete, when $20 \%$ recycled aggregate is added, $28 \mathrm{~d}$ compressive strength of concrete will be improved. The reason is the water absorption of recycled aggregate is far greater than that of the gravel, some water has been absorbed by recycled aggregate, which reduces the water cement ratio of concrete objectively, to a certain extent, it makes up for the loss of compressive strength caused recycled aggregate. In addition, because the irregular edge and corner, rough surface, thus increasing the friction between the particles, delaying the speed of destruction, to a certain extent, improving the compressive strength of concrete. (2) when the recycled aggregate substitution ratio is more than $40 \%$, compressive strength of concrete lower, the influence of aggregate their properties on the compressive strength performance of concrete is more obvious, the main reason is when the replacement ratio of recycled coarse aggregate is less, some of the water is absorbed by recycled coarse aggregate, which make water cement ratio decreased, resulting in the increase of concrete compressive strength, while the replacement ratio of recycled aggregate is larger, the actual water cement ratio is lower, but the concrete compressive strength tends to be determined by its own properties of recycled aggregate, therefore, compressive strength of recycled concrete is not increased along with the further reduction of water cement ratio.

Tab.3 The mixture proportion of concrete

\begin{tabular}{cccccccc}
\hline $\begin{array}{c}\text { specimen } \\
\text { number }\end{array}$ & cement & sand & gravel & $\begin{array}{c}\text { per unit volume of material/ }\left(\mathrm{kg} / \mathrm{m}^{3}\right) \\
\text { recycled } \\
\text { aggregate }\end{array}$ & water & slump & $\begin{array}{c}\text { performane } \\
\text { density }\end{array}$ \\
\hline Z0 & 416 & 856 & 989 & 0 & 183 & 77 & 2400 \\
Z20 & 416 & 856 & 791.2 & 197.8 & 183 & 70 & 2356.6 \\
Z40 & 416 & 856 & 593.4 & 395.6 & 183 & 63 & 2307 \\
Z60 & 416 & 856 & 395.6 & 593.4 & 183 & 44 & 2263 \\
Z80 & 416 & 856 & 197.8 & 791.2 & 183 & 28 & 2212 \\
\hline
\end{tabular}

\section{Influence on elastic modulus of concrete}

Results for each group of concrete elastic modulus test are shown in Table 4. As can be seen in Table 4 , the replacement rate of recycled coarse aggregate has a certain influence on the elastic modulus of concrete, with the increase of the replacement rate of recycled coarse aggregate, the elastic modulus of concrete decreases, and when the recycled coarse aggregate replacement ratio is $100 \%$, the elastic modulus decreases by $46 \%$. The main reason for the decrease of the modulus of elasticity of recycled 
concrete is that the elasticity modulus of recycled aggregate is lower and the void ratio of recycled concrete is higher.

Tab.4 Mechanical properties of recycled concrete

\begin{tabular}{ccccccc}
\hline number & $\mathrm{Q}_{0}$ & $\mathrm{Q}_{20}$ & $\mathrm{Q}_{40}$ & $\mathrm{Q}_{60}$ & $\mathrm{Q}_{80}$ & $\mathrm{Q}_{100}$ \\
\hline $\begin{array}{c}\text { compressive strength } \mathrm{MPa} \\
\text { compression elastic }\end{array}$ & 30.6 & 30.8 & 30.2 & 27.2 & 26.3 & 25.4 \\
Modulus $\left(\times 10^{4}\right) \mathrm{MPa}$ & 3.38 & 2.97 & 2.62 & 2.29 & 1.98 & 1.82 \\
\hline
\end{tabular}

\section{Conclusion}

(1) Making use of recycled aggregate concrete, it can improve the workability of concrete, reduce the apparent density, and improve the use of recycled concrete.

(2) The replacement ratio of recycled aggregate and water cement ratio are two important factors that affect the strength of recycled concrete. Water cement ratio is low, the recycled coarse and fine aggregate has little influence on the strength of recycled concrete, and replacement ratio is right, the compressive strength can be even higher than that of the reference concrete.

(3) This research that construction waste is made of Recycled aggregate, which can be used to replace the natural aggregate to make recycled concrete.

\section{Acknowledgements}

This work was financially supported by the Department of Education of Jilin Province“" 13th Five year" Science and Technology Research Project[2016]-538.

\section{References}

[1] T Du, Y Zhang, YH Chang. Journal of Hunan Urban Construct in College.2002,11(2):35-36.

[2] Khatib J M. Cement and Concrete Research, 2005(35):763-769.

[3] Saroj Mandal, Arundeb GUPTA. Australia: Labse Symposium Melbourne, 2002.

[4] J Wang, YF Xue, H Zhou . Concrete, 2006 (7):47-49.

[5] Yamatoetal T. ACI Speclal.1998, 17(1):25-27.

[6]LuKaian . Construction Technology, 1999 ( 5) : 44-45.

[7] LC Wang, YC Zhao. Beijing: Chemical Industry Publishing House, 2004.

[8] JP Hou, W Shi, YP Song .Architecture Technology, 2002,33(1):15-17.

[9] JS Shen, YD Xu, SQ Zhou, et all. New Building Materials, 2007(8):18-20.

[10] YM Zhang, HG Qin. Concrete and Cement Products, 2002(1):7-9. 